\title{
Sino-Bulgarian Economic Relations in the Post Pandemic World ${ }^{1}$
}

Received: 06.12.2020

Available online: 28.06.2021

\author{
Hongxing Cao*, Huirong Zhan**, \\ Yuan Wang ${ }^{\star \star *}$, Ziyao Wei ${ }^{\star \star \star \star}$
}

in 1949. Since then, Bulgaria and China have established a very good and strong relationship in different ways. However, the outbreak of COVID-19 in 2020 has brought many challenges for both Bulgaria and China, which has a deep impact on the bilateral economic relations.

Therefore, by searching the past ten years of SSCl literature in the database, this paper systematically sorts out the existing research on Sino-Bulgarian economic relations and makes a comprehensive review, reflecting the latest and changing landscape of the Sino-Bulgarian economic relations. Then by collecting, screening and analyzing the latest statistical data in multiple sources, this paper identifies the characteristics of FDI, the bilateral trade respectively. The purpose is to provide a guidance of the prospect of SinoBulgarian economic relations in the future. The paper establishes that the economic relations between the two countries have made great progress under this initiative and new mechanism but still remain unstable and far below their potential. Finally, the paper concludes that there is a very promising future for the bilateral economic relations even

1 The authors thank the financial support from Beijing Foreign Studies University First Class Discipline Construction Projects: "China's investment research in Central and Eastern European countries" (YY19ZZB014) and "Chinese Companies' Marketing Strategy in Central and Eastern European Countries" (YY19ZZA006).

Associate Professor, PhD, International Business School, Beijing Foreign Studies University

${ }^{* *}$ Corresponding Author: Associate Professor, PhD, International Business School, Beijing Foreign Studies University

${ }^{* \star *}$ Master student in Financial Engineering, International Business School, Beijing Foreign Studies University

${ }^{\star * \star *}$ Master student in Financial Engineering, International Business School, Beijing Foreign Studies University 


\section{Articles}

facing many challenges and risks in the post pandemic world.

Keywords: FDI; Trade; Sino-Bulgarian; Economic relations; Post Pandemic JEL: F21, F23, F40

\section{Introduction}

In order to accomplish five major goals: promoting policy coordination and facilitating connectivity, unimpeded trade, financial integration, and people-to-people bonds, the Belt and Road Initiative (BRI) was proposed in 2013, which consists of the Silk Road Economic Belt and the New Maritime Silk Road. Nowadays the BRI has set up a new platform for international investments and trade and is playing a more and more important role for world economic growth. As a regional cooperation strategy, the so-called "16+1" cooperation mechanism that aims to promote the cooperation between China and 16 Central and Eastern European countries (CEECs) was officially launched in 2012. From then on, the cooperation between China and CEECs moved on a fast track. With the joining of Greece into " $16+1$ " on April 12, 2019, this regional cooperation platform between China and CEECs was extended to " $17+1$ ", which constitutes an integral part of the cooperation between China and Europe, and is also a beneficial supplement to the cooperation between China and the EU. In the near future, the "17+1" cooperation mechanism would be well built together with $\mathrm{BRl}$, the Eurasia interconnection strategy, the three seas initiative and the development strategy of CEECs.

Bulgaria, one of CEECs, has deep traditional friendship with China and its low tax, increasing consumption power and strategic geographical location make Bulgaria one of the most important partners in the CEE region. Furthermore, under the $\mathrm{BRI}$ and " $17+1$ " cooperation mechanism, the Sino-Bulgarian
Sino-Bulgarian Economic Relations in the Post

Pandemic World

economic relations have become better and better in recent years. However, the outbreak of the COVID-19 pandemic in the beginning of 2020 has resulted in huge negative effects on the global economy. Besides this, the cooperation between China and CEECs has entered the deep-water zone since 2017 and is facing a lot of challenges. The bilateral cooperation between China and Bulgaria will operate under the "double downward" pressure from the global and domestic economies in the near future.

How have the economic relations between China and Bulgaria changed during the last two decades? What are the impacts of the COVID-19 pandemic on Bulgaria's economy and Sino-Bulgarian bilateral trade? Are there some new potential cooperation fields and challenges in the post pandemic world? This paper attempts to answer these questions. Therefore, in the second part, this paper gives a short review on the history of the SinoBulgarian relationships, providing a research background for the next sections. In the third part, this paper systematically sorts out the existing literature on this topic. In the fourth part, by collecting and analyzing the data from different authoritative sources, this paper explores the characteristics of FDI, import and export trade between China and Bulgaria. This paper analyzes the current situation of the economic relations in the pandemic world and proposes the prospects for the future in the fifth part. The conclusions are given in the sixth part.

\section{The history of the Sino-Bulgarian relationship}

Bulgaria is located in the southeast of the Balkans, and joined NATO and the EU in 2004 and 2007 respectively. Although far away from China, Bulgaria was the second country that recognized and established diplomatic relations with China on October 


\section{Articles}

4, 1949. In the 1950s, the relations between the two countries developed very fast. In 1952, China and Bulgaria signed the first cultural cooperation agreement in Sofia and the first trade agreement using the Clearing Account Trade. In 1955, the two countries signed the first intergovernmental agreement on science and technology cooperation and later established the government science and technology cooperation committee. However, during the Cultural Revolution in China (19661976), the relations between the two countries almost stopped because of the deterioration of Sino-Soviet relations. The cooperation relations in trade, culture, and ocean shipping gradually recovered in the late 1970s. In the 1980s, due to the deepening of China's reform and opening-up, the two countries not only resumed high-level visits and exchanges between parliaments and political parties, but also witnessed a rapid economic and trade development. In 1985, China and Bulgaria established an Intergovernmental Commission for economic, trade, scientific and technological cooperation, which was cochaired by the deputy ministers of economy of the two countries.

China and Bulgaria have maintained good relations during the first two decades of the $21^{\text {th }}$ century. In June 2007, the name of commission was changed to the Intergovernmental Joint Commission for Economic Cooperation, which is a very important mechanism for the development of trade and economic relations between the two countries because any opportunities for deepening bilateral cooperation in areas of common interest have been discussed in each session of the commission (Kandilarov, 2015). In 2009, the two sides signed a memorandum of understanding on economic cooperation between the two countries. In 2014, the two countries established the all-round cooperation relationship which enhanced the cooperation between the two countries. In the same year, the China-CEE Association for the Promotion of Agricultural Cooperation was established in Sofia. In 2018, China's first agricultural industrial demonstration park in the EU was officially unveiled in Bulgaria. In recent years, the leaders of China and Bulgaria have kept close contacts. Chinese Premier Li Keqiang held bilateral meetings with the Prime Minister of Bulgaria in each of the China and CEE summits during 20162019. In July 2018, Premier Li Keqiang paid his first official visit to Bulgaria and attended the seventh China and CEE leaders' meeting held in Sofia, which made the relations between China and Bulgaria heat up rapidly. In July 2019, the two countries issued the joint statement on the establishment of strategic partnership. In January 2020, the $17^{\text {th }}$ meeting of the Intergovernmental Economic Joint Committee of China and Bulgaria was held in Beijing. In contrast to the long history of cooperation between China and Bulgaria, the researches on the economic relations between the two countries are much less than their counterparts within the framework of BRI and CEE.

\section{Literature Review}

By searching the past ten years of existing SSCI literature in Taylor \& Francis, Elsevier, EBSCO, Emerald, Willey Online, JSTOR, and Web of Science, this paper suggests that more researches about the Sino-Bulgarian economic relations are needed to reflect the latest and changing landscape of the SinoBulgarian economic relations.

The review of the literature in this section is divided into three subsections. Firstly, the paper presents the main and important results related to the BRI. Then this paper analyzes the recent literature on FDI and bilateral trade. Thirdly, this paper focuses on the research 


\section{Articles}

results of the economic relations between China and Bulgaria.

\section{BRI}

Since 2013, there have been increasing interests and fruits about the BRI-related researches, which can be categorized into two schools: one is the discussion about the economic influence of BRI, the other is the study about the FDI and trade in the BR economies.

$\mathrm{BRI}$ is regarded as a Chinese global grand strategy (Clarke, 2017; Beeson, 2018) and the most ambitious Chinese international policy initiative in history, and the purpose of BRI is to promote regional economic development, through the creation of win-win cooperation and joint prosperity (Huang, 2016). Foreign direct investment, trade and infrastructure and construction are three main areas for mutual cooperation among the economies along the BR. During the years of 2013 to 2019, the total amount of goods trade between China and the BR countries exceeded 7.8 trillion US dollars, and the direct investment exceeded 110 billion US dollars, with nearly 800 billion US dollars of the newly signed construction contracts (Zheng \& Wang, 2020). Ahmed (2018) mentioned that the BRI would affect the lives of about 80 percent of the world population from 65 countries in Asia, Europe and Africa, and the estimated cost of the BRI was nearly 2.1 trillion US Dollars.

China has emerged as an international hub for manufacturing activities, with its cheap labor and deregulation reforms instituted by the government during the last two decades. The determinants of the country's achievements can be summarized as high demand for Chinese exports, FDI in the industrial sector and price competitiveness (Paul, 2016). Many scholars also mention that despite the remarkable growth, China faces many challenges in terms of poverty, unemployment, etc. (Paul, 2016). There are a lot of growing
Sino-Bulgarian Economic Relations in the Post

Pandemic World

concerns about the sustainability of China's domestic growth model. Some observers claim that one of the BRI's principal attractions is its potential to solve the growing problem of surplus domestic capacity (Lo, 2015). It is important to recognize that without an underlying transformation in the structure and scale of the Chinese economy, the influence of any Chinese leader, no matter how able or proactive, would be significantly reduced (Beeson, 2018). Moreover, the implementation of BRI itself also faces some barriers such as politics, policy coordination, project management and financial sustainability (Huang, 2016).

Some studies imply an important economic influence of the BRI on the economies along and beyond $\mathrm{BRI}$ routes. Many scholars think that the BRI has an immense symbolic and practical importance. Khan et al. (2018) highlighted China's motivation for developing $\mathrm{BRI}$ as an internal and external policy framework for an inclusive and openly "winwin" cooperative, global-development model based on shared interests. Zhai (2018) investigated the macroeconomic impact of China's BRI and found that the BRI would bring sizable benefits to the world economy in terms of welfare and trade, even under conservative assumptions about the size of the total investment under the initiative, accounting for the externalities of infrastructure development with respect to trade cost reduction and energy efficiency improvement.

However, there is considerable optimism about BRI across Asia, as well as concern and skepticism regarding China's ultimate intentions and ability to deliver on its promises. Meanwhile, the Southeast Asian countries are divided on the extent to which they should participate in BRI. Countries such as Cambodia, Laos, and Myanmar support the initiative and are prepared to participate. However, other countries, such as Vietnam, 


\section{Articles}

Indonesia, Malaysia, and the Philippines, are taking a more cautious approach toward $\mathrm{BRI}$ due to their concerns about the security risks of economic over-dependence on China (Clarke, 2017). Some researchers have negative attitudes and view the BRI as one of the most controversial issues in the world (Malik, 2018). Many governments in the EU are concerned about the impact of statesubsidized competition on the still fragile and under-performing economies of Western Europe (Casarini, 2016). Besides this, the cooperation between China and CEECs has entered the deep-water zone since 2017 and is facing a lot of challenges such as the changes in the EU's China policy, the Sino-US trade frictions, the different opinions on the cooperation with China among CEECs and China's New Normal (Liu, 2020).

Although $\mathrm{BRI}$ is an economic strategy, some scholars discover the close interaction between politics and economics in many aspects of $\mathrm{BRI}$ from the perspective of geopolitics. Flint and Zhu (2019) regarded BRI as a mixture of all three goals and strategies: economic integration, regional influence, and global geopolitical competition. Narins and Agnew (2019) argued that the driving impetus for the BRI were realizing the "China Dream", improving China's international economic connectivity and enhancing China's global infrastructural investment and trade, which reflect China's desire to regain its historic centrality in world affairs.

Blanchard (2017) pointed out that economics and politics were intimately related regarding the objectives and the challenges of the Maritime Silk Road Initiative (MSRI). Blanchard and Flint (2017) interpreted the MSRI as a geopolitical project that blended tactics of economics and politics, and analyzed the close interaction between political and economic factors in the design, implementation and outcomes of the MSRI.

\section{FDI}

When it comes to economic relationships between two countries, FDI, especially its determinants, has always been one of the focuses of research. Mumtaz (2018) investigated the determinants of Chinese outward direct investment (ODI). The empirical results by Du and Zhang (2018) indicated China's enterprise ownership would have an impact on the sectors they choose to invest. Iqbal et al. (2019) applied the panel data regression technique and revealed that inflation rate, export, import, corruption, infrastructure and geographic distance were the significant determinants of China's investment in Asia.

In response to BRI, China's FDI, especially whole or majority-ownership mergers and acquisitions, rose significantly in the BR countries. Zhang (2016) discovered the investment facilitation level along the BR and analyzed its impact on OFDI based on the principal component analysis of the trade gravity model. Fan et al. (2016) constructed a frontier regression model to assess China's outward FDI efficiency and its determinants in countries along the BR. Liu et al. (2017) found out that Chinese OFDI in BR countries were highly sensitive to exchange rate (ER) level, market potential, openness, and infrastructure facilities of host countries. Wang et al. (2018) used the double differential method to test the location selection in China's OFDI, and established that the $\mathrm{BRI}$ significantly promote China's OFDI in BR countries. Lu et al. (2018) analyzed the impact of China's OFDI on 48 BR countries on the extensive and intensive margins of trade, and established that the trade creation effect of Chinese OFDI derived mainly from increases in the intensive margin of trade. Li et al. (2019) found out that both overall economic freedom (EF), the interaction of EF and institutional instance, bilateral trade, 


\section{Articles}

GDP, and patent significantly influenced OFDI from China to 12 countries along the BR.

The topic related to FDI in the CEE region has also attracted much attention all over the world. After Hunya and Galgoczi (2006) summarized the quality and characteristics of trade and FDI in CEECs from 2000 to 2005, the later literature on investment and trade in CEECs included the more appropriate measure of tax burden on FDI (Bellak et al., 2007) and the mathematical relationship between global financial crisis and FDI (Dornean et al. , 2012). Thereafter some scholars began to focus on China's FDI in CEECs. Turcsanyi (2016) discussed the attitudes of CEECs on China's energy investment. Matura (2019) suggested a strong and positive correlation between bilateral political relations and China's FDI in CEECs but a very weak correlation between bilateral political relations and trade between China and CEECs. Therefore, in order to protect domestic investment better, China tends to invest in CEECs with better political relations with China (Li \& Liang, 2012; Liu, 2014).

While Chinese scholars tend to use empirical methods to study China's FDI in CEECs, as well as its investment environment (Liu, 2013), fields, distribution (Zhang, 2017) and influence (Yang and Chen, 2016). Liu et al. (2020) observed the efficiency and potential of China's OFDI in CEECs and the finding implied that China had higher efficiency and potential in EU members like Bulgaria, Romania and Hungary.

\section{Trade}

There are many studies about trade in the context of the BRI. Chen and Yang (2015) found that the trade between China and the BR countries tended to be balanced, while China's trade surplus widens, and there was a huge space for developing the trade. Kohl (2019) employed gravity equation to estimate the BRl's effect on supply trade
Sino-Bulgarian Economic Relations in the Post

Pandemic World

for 64 economies under various scenarios and deduced that infrastructural investments would yield asymmetric benefits to China, Russia and the Southeast Asian countries.

Some scholars are interested in examining the exports trade. Wang et al. (2019) compared the economic factors that affected China's exports along the BRI. They drew a conclusion that the BRI stimulated China's exports and a shared border, a similar legal system and the existence of free trade agreements had a strong positive effect on China's exports to countries along the BR. Cui and Song (2019) revealed that the significant potential for cooperation between China and the BRI countries still existed although the trade barriers were prominent for some sectors. The research provided evidence that the BRI improved economic growth and social welfare for the participating regions. Mao et al. (2018) indicated that the BRI has a positive impact on node countries' exports to China but the effects differ in different regions.

As China's trade volume rapidly grows, China might be considered as a competitor and threat to the European market. But Poncet (2015) argued that the competition between China and European countries are not as severe as one might imagine based on the analysis from the industry level and market segmentation.

\section{Bulgaria}

The above-mentioned papers focus more on the economic relationship among the member states of BRI or CEECs and China, without elaborating on the economic and trade exchanges between China and Bulgaria. Bulgaria is often referred as a leader in the field of agriculture in CEECs and holds the cooperation mechanism in agriculture. In 2019 , the agricultural trade volume of SinoBulgarian was 82.802 million US dollars, with a year-on-year growth of $54.2 \%$. Both China and Bulgaria expect to deepen their cooperation 


\section{Articles}

in different industries. The following papers separate Bulgaria from the BR countries and CEECs, and discuss its economic relations with China.

Shang and Gao (2014) used the empirical method to analyze the effect of product competitiveness and goods structure on bilateral trade performance. The results indicated that Bulgaria and other CEECs have a strong competition in intermediate goods. Kandilarov (2015) pointed out that Bulgaria hoped to deepen cooperation with China in tourism, agriculture, food, energy, science, education and culture through the BRI and "17 + 1" platform. Moreover, the high-addedvalue and competitive sectors in Bulgaria may attract more Chinese investment in the future. Kameliya (2016) then calculated the BulgariaChina trade competitiveness index and found out that Bulgaria's stable and strong currency and low inflation rate had a positive impact on the trade with China, but its slow economic growth and unstable economic situation hinder the further development of bilateral trade. Kandilarov and Dimitrov (2018) put forward the understanding for the BRI and " $16+1$ " platform from the perspective of Bulgaria and the EU. In addition, this paper discussed the relationship between Bulgaria and China from the aspects of cooperation projects and diplomatic relations, and analyzed the mechanism and promising opportunities of the economic cooperation between China and Bulgaria. Kandilarov and Wang (2018) reviewed the China-CEECs diplomatic relations during the past 40 years and summarized that the BRI has profoundly changed the political and economic situation in the Eurasian continent, which provides numerous cooperation opportunities for CEECs and Bulgaria, coexisting challenges. Based on the data from the year of 2007 to 2017, Zhelev (2018) mainly employed various trade indicators including trade complementarity, Intra-industry trade, revealed comparative advantage indices to review the trade relations between Bulgaria and China. The FDI from China to Bulgaria in the same period was also analyzed and then potential cooperation fields between two countries were proposed in the end. Jiang (2020) found out that the economic cooperation between China and Bulgaria had greatly strengthened, benefiting from the BRI and "17+1" cooperation mechanism. There are five major sectors in the Sino-Bulgarian economic and trade cooperation fields: agriculture and food processing, automobile industry, information technology, finance and engineering. But the future was not as bright as it might be seen because of the four challenges: lacking of sufficient understanding between firms and people of the two countries, certain risks arising in the agricultural area, the negative effect resulted from the failure cooperation cases and particular constraints on the SinoBulgarian cooperation from the EU etc.

The economic relations between China and Bulgaria in detail have been described from various aspects as the above, but there were few in-depth studies on Sino-Bulgarian. These papers do not summarize the bilateral trade and investment between China and Bulgaria, and analyze their trends and reasons from a historical perspective. Moreover, the COVID-19 pandemic in 2020 has resulted in some sudden changes in the international economic environment. Therefore, reviewing and exploring the situation of economic relations between China and Bulgaria will play a key role for the future cooperation.

\section{Review of the Economic relations between Bulgaria and China}

This section mainly discusses the OFDI flow and stock from China during 20032018, FDI projects in Bulgaria, bilateral trade between China and Bulgaria during 2003- 
Articles

2019 based on the data collected from diverse official sources including the Ministry of Commerce of PRC, China Customs, Eurostat, China Statistics Bureau.
Sino-Bulgarian Economic Relations in the Post

Pandemic World
China's FDI Flow and Stock in Bulgaria

This paper divides China's FDI in Bulgaria into three periods based on the FDI stock data as follows (Fig. 1).

Fig. 1. China's FDI Flow and Stock in Bulgaria from 2003 to 2018 (Unit: 10000 US dollars)

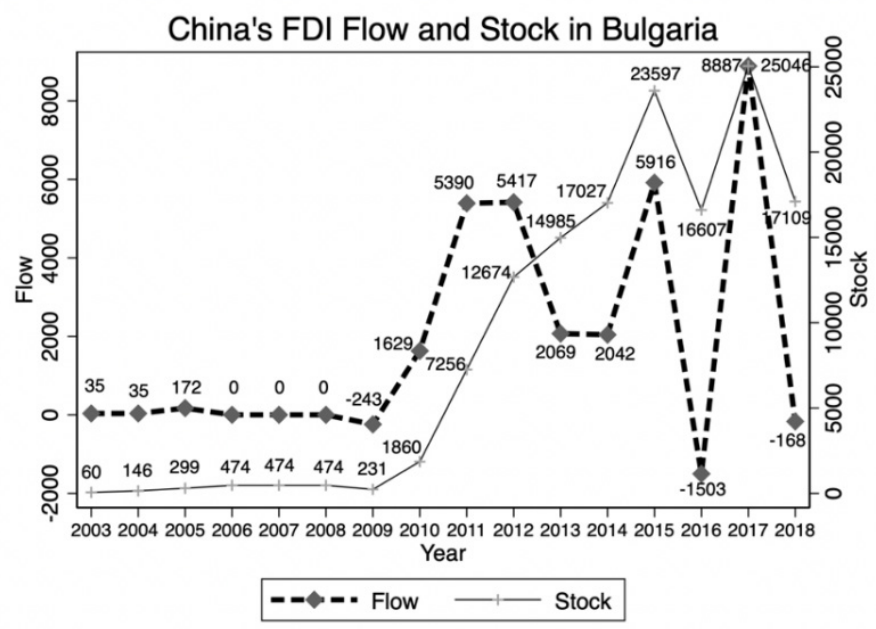

Source: Ministry of Commerce of the People's Republic of China

(Note: the data of China's FDI flow to Bulgaria from 2006 to 2008 is missing, which is replaced by 0.)

\section{3-2009: Remain Low and Stable}

Investment and cooperation between the two countries have a long history, but China has not been one of the main sources of FDI in Bulgaria, and the two countries have not had any currency swap agreement so far. The main sources of FDI in Bulgaria are the developed countries in Europe. The FDI stock of the Netherlands, Austria, Greece, Germany and Italy in Bulgaria have been maintained at a high level.

It can be seen from Figure 1 that the flow and stock of China's FDI in Bulgaria remained at a low level from 2003 to 2009. One reason for this was that Asian countries have been China's first choice for FDI in those seven years. Although China's investment in European countries has been growing rapidly, the proportion of China's FDI to Asia has always been more than $50 \%$. The second reason was that China's FDI mainly went to leasing and business services at that time, while the service industry was the pillar industry of Bulgaria, so its external demand was relatively small. Bulgaria attracted FDI in finance, real estate and other fields with a high rate of return and quick return. Thirdly, most of Bulgaria's infrastructure, such as roads, railways, ports and airports, were built in the 1960s to $80 \mathrm{~s}$, and the phenomena of aging and out-of-repair generally existed, which restricted the FDI of China to Bulgaria to a certain extent. The fourth reason was that since Bulgaria became a member of EU in 2007, the amount of financial aid from the EU received by Bulgaria has increased significantly, which could support the development of the country's agriculture, 


\section{Articles}

infrastructure construction and the development of its small and medium-sized enterprises. Therefore, the flow and stock of China's FDI in Bulgaria have not increased but decreased during 2003 to 2009.

\section{0-2015: Start Climbing}

However, the situation reversed in 2010. The Greek debt crisis arising at the end of 2009 had a lot of adverse effects on Bulgaria. On the one hand, Greece, as Bulgaria's largest exporter, was in the deep debt crisis, which hindered Bulgaria's export. On the other hand, the debt crisis has increased regional economic risk of $\mathrm{CEE}$, including Bulgaria, leading to the stagnation of attracting FDI in the area. Bulgaria's economy is export-oriented, with a small scale and high dependence on FDI. After the Greek debt crisis, the EU that Bulgaria originally relied on has been more or less affected. Therefore, Bulgaria needed to attract FDI from outside the EU like China as soon as possible to achieve economic recovery. As Liu (2014) mentioned that the Greek debt crisis offered a "window of opportunity" to China.

In addition, in 2008 and 2009, China and Bulgaria reached cooperation in the administrative reform and health medicine sector respectively. In October 2009, The then Vice President Xi Jinping visited Bulgaria and signed a memorandum of understanding and cooperation between the economic, energy and tourism sectors. As can be seen from Figure 1, during 2010-2015, although the flow of China's FDI in Bulgaria has fluctuated, both the flow and the stock have increased significantly.

\section{6-2018: Continue Fluctuating}

The year of 2016 was a year of turmoil in Bulgaria. During the regime change, the election process was full of accidents. Waves of demonstrations were set off, and the country's economy was greatly affected.
China's FDI in the EU surged $82.4 \%$ to 9.994 billion US dollars in 2016, and its FDI in CEECs also increased significantly. However, under such circumstances, China's FDI in Bulgaria fell to the lowest level after 2003. A change happened in 2017, despite of a decline of China's FDI in the EU, the one in Bulgaria rose to 88.87 million US dollars. In 2018, the EU's regulatory scrutiny on investment and acquisitions was increasingly stringent. At least seven of China's deals in Europe which worth 1.5 billion US dollars in total were cancelled due to the latest investment regulatory scrutiny. China's FDI to Europe decreased by $64.3 \%$ to only 6.59 billion US dollars. In addition, China's domestic financial environment further tightened in 2018. Under the double pressure, the FDI flow of China to Bulgaria declined again.

\section{FDI projects in Bulgaria}

Based on the above analysis, it is easy to see that China's FDI volume in Bulgaria is not stable and low in spite of the many favorable factors. Furthermore, compared with the greenfield foreign direct investment, China is more interested in mergers and acquisitions, public procurement tender opportunities for infrastructure construction in CEECs (Jakóbowski and Kaczmarski, 2017). So far, China's greenfield FDI projects in Bulgaria mainly focus on agriculture and food processing, information technology and automotive industry.

There are two big agricultural greenfield investment projects. One is a EUR-10-million investment by the Tianjin Agrobusiness company. It leased 20000 acres of land in northwestern Bulgaria to grow corns for exports to China (Zhelev, 2018). In 2019, this investment volume has reached 58.6 million US dollars. Another is a feed production plant near Dobrich, built in 2016 by the China Tianjin Tianshinong Farming Technology Ltd.. The investment amounted to 10 million 


\section{Articles}

euros in the first phase of the feed plant. It is estimated that the company not only purchases in Bulgaria every year 20-millioneuro agricultural products but also increases exports by about 30 million euros for Bulgaria.

Huawei Technologies is the largest Chinese company and major supplier to the telecommunication market in Bulgaria. Huawei Bulgaria was founded in 2004. In June 2017, Huawei Bulgaria and Bulgarian Telecom announced that they would jointly build a cloud Center for Bulgaria and help Bulgaria build a "smart country". A survey by Oxford Economics shows that Huawei contributed 43.8 million euros to the Bulgarian economy in 2019 , or $0.08 \%$ of Bulgaria's gross domestic product. The company's contribution to the Bulgarian economy has been on a clear upward trend in recent years. The company's average annual growth rate between 2015 and 2019 was $10.1 \%$. The company also directly or indirectly creates more than 1,100 jobs, representing $0.03 \%$ of the Bulgarian job market. The average annual growth rate of jobs provided by the company is 12 percent.

In March 2018, the Chinese company ThunderSoft merged with MM Solutions, the
Sino-Bulgarian Economic Relations in the Post

Pandemic World

world's leading image and vision technology company in Bulgaria, which enhanced the global influence of ThunderSoft and helped MM Solution have better development in technology, industry resource and markets (Jiang, 2020). This merger and Huawei's cloud center marked the cooperation between China and Bulgaria in the area of digital economy.

The Chinese auto-producer Wall Motors built a joint venture with the Bulgarian counterpart Litex Motors in a car assembly plant near Lovech in 2012, however, this notable investment went bankrupt in 2017 (Zhelev, 2018).

\section{Bilateral Trade between China and Bulgaria}

This part analyzes the trade volume, trade partners, and export and import product structure between the two countries.

\section{Trade Volume: On the Rise}

It could be seen that from 1997 to 2002 , the bilateral trade volume between China and Bulgaria increased from 47.97 million to 119.1 million US dollars (Table 1).

Table 1. Bilateral Trade between China and Bulgaria between 1997 and 2002 (Unit: 10000 US dollars)

\begin{tabular}{|l|l|l|l|l|}
\hline \multicolumn{1}{|c|}{ Year } & \multicolumn{1}{c|}{ Trade Volume } & \multicolumn{1}{c|}{ China's Export } & \multicolumn{1}{c|}{ China's Imports } & \multicolumn{1}{c|}{ Trade Surplus } \\
\hline $\mathbf{1 9 9 7}$ & 4797 & 3138 & 1659 & 1479 \\
\hline $\mathbf{1 9 9 8}$ & 4799 & 4518 & 260 & 4238 \\
\hline $\mathbf{1 9 9 9}$ & 6266 & 5344 & 922 & 4422 \\
\hline $\mathbf{2 0 0 0}$ & 9430 & 8083 & 1347 & 6736 \\
\hline $\mathbf{2 0 0 1}$ & 11754 & 8908 & 2846 & 6062 \\
\hline $\mathbf{2 0 0 2}$ & 11910 & 9763 & 2147 & 7616 \\
\hline
\end{tabular}

Source: China Customs

The total trade and the import and export volume of the two countries were on the rise in general after 2003 (Fig.2, Fig.3). In 2007, the bilateral trade volume and Bulgaria's imports from China decreased to a certain extent.
This was mainly because Bulgaria joined the EU in 2007, and the trade remedy measures against China, especially anti-dumping and anti-subsidy measures, initiated by the EU restricted the entry of some Chinese products 


\section{Articles}

into the Bulgarian market. However, since then, the bilateral trade and import and export volume have rebounded, because Bulgaria's EU accession also laid a solid foundation for the stable development of bilateral economic and trade relations between China and Bulgaria through its common trade policy, tariff reduction and trade standardization.

Fig. 2. Total Trade Volume between China and Bulgaria from 2003 to 2019

Total Trade Volume between China and Bulgaria (Unit:100 million dollars)

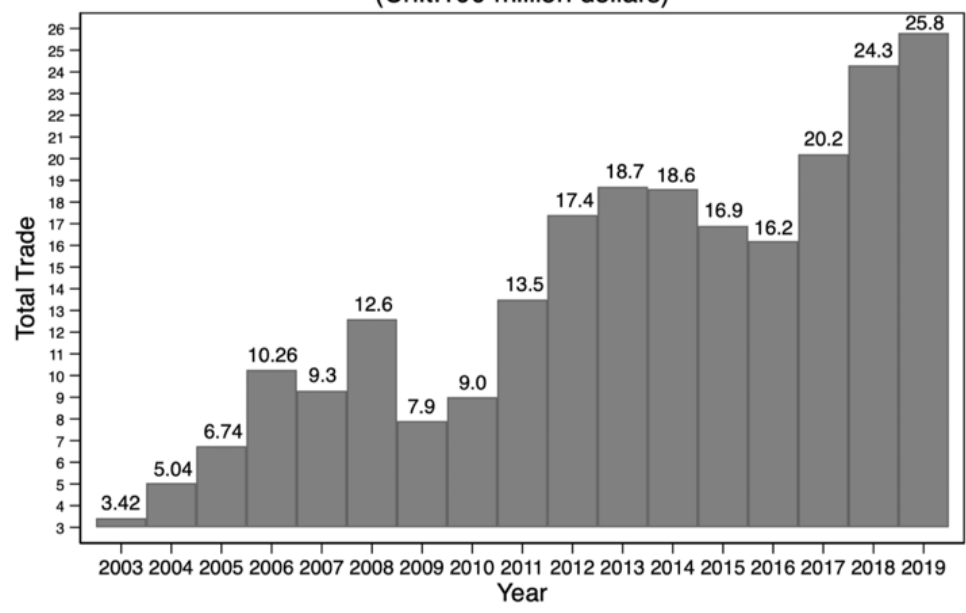

Source: European Statistics

Fig. 3. Volume of Import and Export between China and Bulgaria from 2003 to 2019 Volume of Import and Export between China and Bulgaria (Unit:100 million dollars)

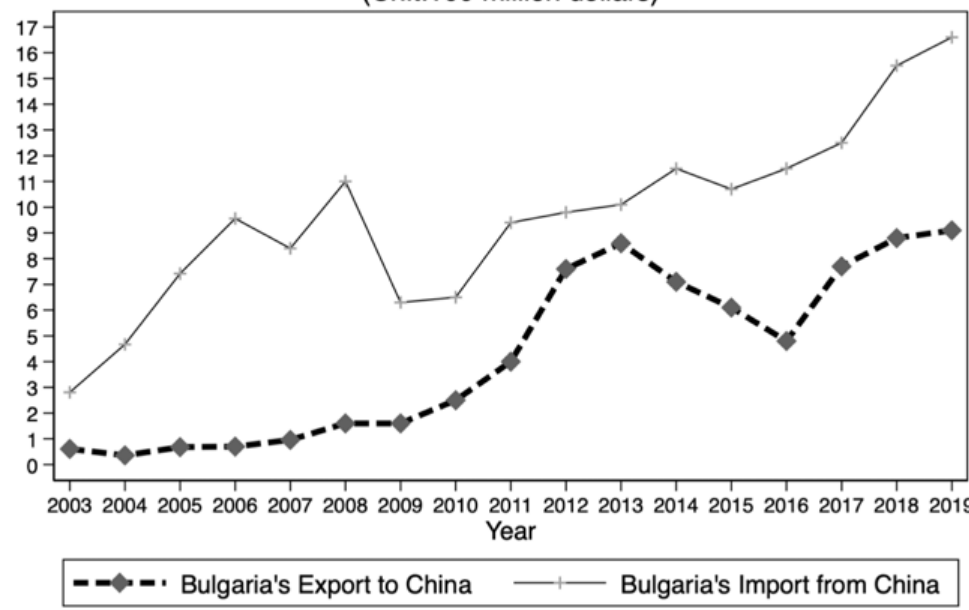

Source: European Statistics

After the outbreak of the global financial crisis in 2008, the import and export situation of Bulgaria in the second half of the year showed a very obvious downward trend, whether compared with the first half of the year or with the same period of the previous year, 


\section{Articles}

which demonstrated that the global financial crisis significantly hindered the import and export of Bulgaria. As one of the countries with the weakest consumption capacity in the EU, Bulgaria's domestic demand declined due to the reduction of FDI and the rise of the unemployment rate brought by the global financial crisis, which squeezed the space of Chinese products in Bulgaria. In the first half of 2008, the growth trend of import and export was significant, so the negative impact of the financial crisis was not reflected in the data of 2008, but in the bilateral trade volume in 2009 and the import of Bulgaria from China. In addition, the outbreak of the Greek debt crisis in 2009 again hit the Bulgarian economy. Although the Bulgarian government took a series of measures, the main domestic macroeconomic indicators deteriorated significantly, and did not recover until 2010.

Since then, the bilateral trade between the two countries has entered a stage of rapid
Sino-Bulgarian Economic Relations in the Post

Pandemic World

development. In 2016, the bilateral trade volume and the export volume of Bulgaria to China showed the same trend as China's FDI flow to Bulgaria, and the reasons were the same. Social unrest led to the temporary stagnation of domestic production in Bulgaria, and the total foreign trade volume of Bulgaria decreased by $14.3 \%$ compared with that in 2014.

After 2016, the economic and trade relations between China and Bulgaria have shown a steady and rising trend, which is mainly reflected in their closer bilateral exchanges, continuous enrichment of economic cooperation forms, smooth progress of most cooperating projects and balanced growth of the bilateral trade volume. In 2019, the bilateral trade volume between China and Bulgaria was 2.58 billion US dollars, reaching the highest level in the history of bilateral trade.

Fig. 4. China's Ranking in Bulgaria's Main Export Markets and Import Sources from 2007 to 2019

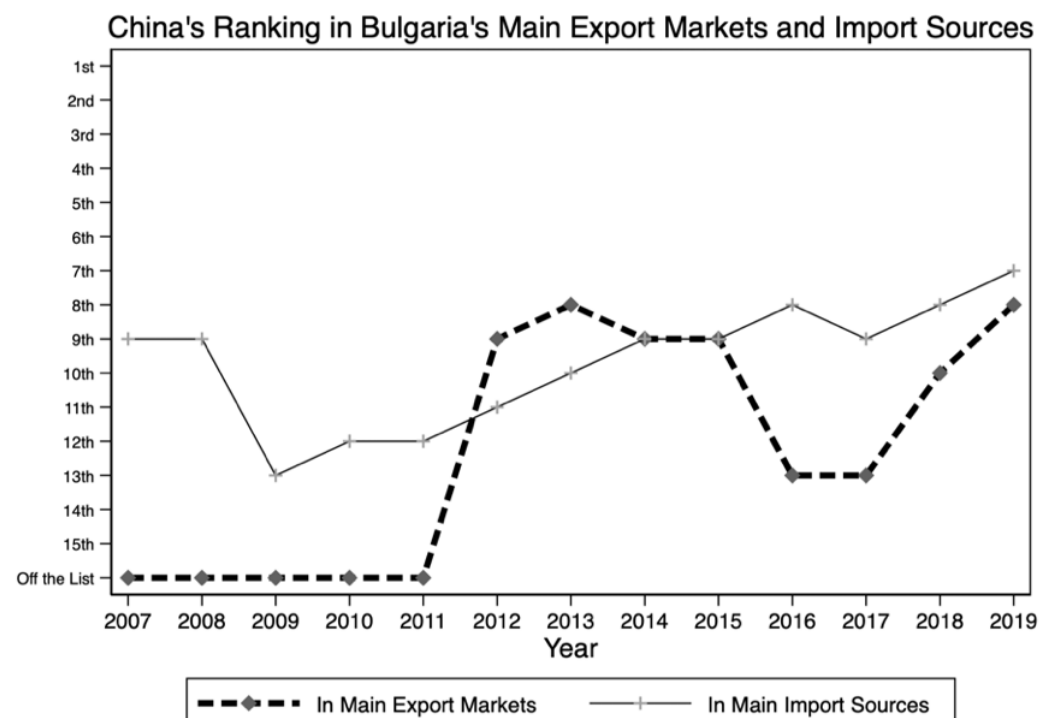

Source: European Statistics 


\section{Articles}

\section{Trade Partner: Ranking Higher}

Although the trade situation between China and Bulgaria has been improving, the total trade volume between the two countries is still low. So far, EU countries remain Bulgaria's largest trade partners, and Bulgaria's import and export volume are greatly affected by the EU countries' demand. However, according to the ranking in Figure 4, China is increasingly playing a more important role among Bulgaria's trade partners. In 2019, China ranked seventh among Bulgaria's major import trade partners and eighth among its major export trade partners, which greatly improved compared with that of 13 years ago.

\section{Trade Products Structure: Increasing but Single}

According to the data released by Eurostat, the main products exported from Bulgaria to China during 2007 to 2019 are base metals and their products, and the second largest category is generally mechanical and electrical products or mineral products. The main products imported from China to Bulgaria changed over the past 13 years: from 2007 to 2011, as well as 2013 and 2017, the top three categories of products Bulgaria imported from China were mechanical and electrical products, base metals and their products, as well as furniture, toys and miscellaneous products; in 2012 and 2014-2016, the top three categories of products Bulgaria imported from China were mechanical and electrical products, chemical products and their products, as well as furniture, toys and miscellaneous products. From 2018 to 2019, the top three categories of products Bulgaria imported from China were mechanical and electrical products, textiles and raw materials, as well as furniture, toys and miscellaneous products. However, as base metals and their products always accounted for a relatively large proportion, in this paper, they were regarded as the third largest category of products that Bulgaria imported from China.

Fig. 5. Export Volume of Main Products from Bulgaria to China in 2007-2019

EXport Volume of Main Products from Bulgaria to China (Unit:100 million dollars)

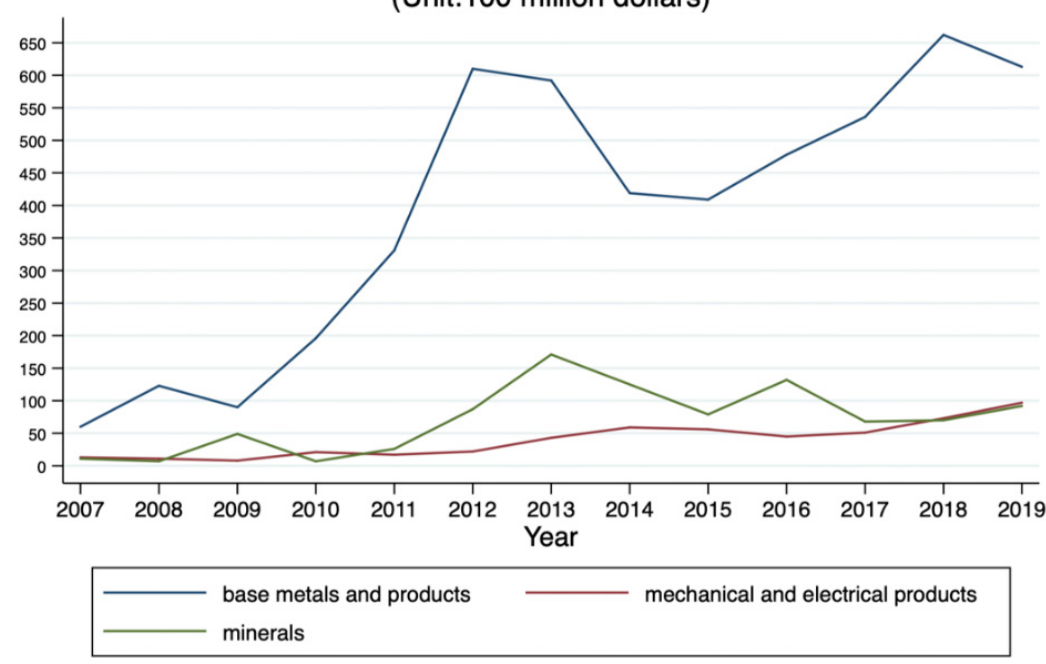

Source: China Statistics Bureau 
Fig. 6. Import Volume of Main Products from China to Bulgaria in 2007-2019 Import Volume of Main Products from China to Bulgaria (Unit:100 million dollars)

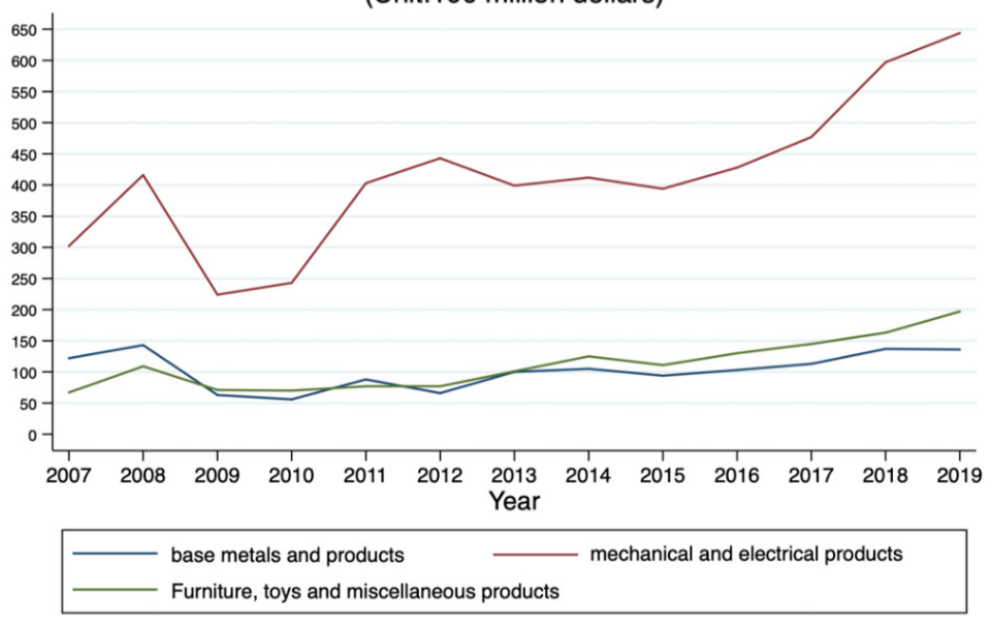

Source: China Statistics Bureau

Figures 5 and 6 calculated the volume of Bulgaria's three major export products and import products during the 13 years from 2007 to 2019 based on the above ranking. It can be seen from the two figures that among the three main export products, base metals and their products are the absolute advantage, while among the main import products, the mechanical and electrical products are far ahead. Although the import and export volume of the main products is growing, the product category is still relatively single. China has more advantages than Bulgaria in labor-intensive products and light industrial products.

\section{Current Situation of Bulgarian Economy Development and Prospect}

This section firstly explores the effect on Bulgarian economy caused by the COVID-19 pandemic and then analyzes the prospect between China and Bulgaria after the outbreak of the pandemic.

\section{Bulgarian Economy Situation in the Context of COVID-19 Pandemic}

In 2020, the outbreak of the COVID-19 pandemic severely hit the global economy. The service industries, especially tourism, restaurant, hotel, airline etc. have been heavily affected. Although Bulgaria's economy achieved $0.3 \%$ growth in the first quarter of 2020, becoming one of the only three EU countries that achieved economic growth in the first quarter of 2020 , the subsequent economic losses caused by the pandemic are still immeasurable because the services sector accounts for two thirds in the structure of Bulgarian GDP.

In addition to macroeconomic indicators, all industries in Bulgaria have been affected to a certain extent. The profits of Bulgaria's banking industry shrank by nearly $60 \%$ in April 2020, according to the National Bank of Bulgaria. In the same month, new car sales in its auto industry fell by $73 \%$ yearon-year. Tourism is one of the hardest hit industries: according to the data released by Sofia Airport on May 25, the passenger 


\section{Articles}

flow of Sofia Airport decreased by $94.2 \%$; in August, the number of inbound tourists in Bulgaria decreased by $67.9 \%$. In the second quarter of 2020, the turnover of real estate in Bulgaria was 37903 sets, which was far lower than 52503 sets in the same period of 2019, shrinking by nearly $30 \%$. In addition, due to the impact of the pandemic, the production capacity of Bulgaria's traditional advantage, rose planting, may only be maintained at $50 \%$ compared to last year.

The pandemic has made a large number of workers return to Bulgaria, leading to a sharp rise in the domestic unemployment rate. Table 2 shows the unemployment rate of Bulgaria from March to December 2020. In March 2020, the registered unemployment rate in Bulgaria reached $6.7 \%$. After March 13th, 26300 unemployed people were registered in the Labor Bureau, 14500 people of which said the coronavirus crisis was the main reason. Among the newly unemployed, the majority are employees in hotels, restaurants, trade and manufacturing sectors. Bulgaria's unemployment rate reached a peak of $9 \%$ in May. The Bulgarian government has taken a series of measures, such as the "40 / 60 support plan", which means that "enterprises should bear $40 \%$ of the wages of employees who are out of business during the pandemic period, and the state will pay the rest 60\%". According to the data released by Bulgaria's national employment agency, the registered unemployment rate was $7.5 \%$ in August, and many unemployed people have achieved reemployment. Although the unemployment rate in Bulgaria gradually decreased in the last four months of 2020 , compared with $5.6 \%$ in October 2019 and 5.8\% in November 2019, the situation was still not optimistic.

Under this circumstance, the Bulgarian government has actively taken measures to restore its domestic economic and industrial conditions. By June 2020, Bulgaria's construction output was increasing for two consecutive months. In the same month, Bulgaria's retail trade volume increased by $0.9 \%$ month on month. In addition, online shopping transactions increased by $35.5 \%$. However, the Bulgarian central bank pointed out in its Autumn Macroeconomic Forecast that the road to recovery of Bulgaria's national economy is still very long, and it is expected to return to the pre-pandemic level in the middle of 2022.

As for the effect on the bilateral trade resulting from the pandemic, some results can be implied from Table 3. Compared with the same period of 2019 , the cumulative total volume presents a remarkable upward trend in 2020 while its growth rates over the same period last year of trade were negative in the first seven months of 2020 and then started to be positive since August. Although the cumulative growth rates of export from China to Bulgaria each month in 2020 are negative, the trend of the bilateral trade is optimistic. The cumulative growth rate of imports from Bulgaria to China has already increased by more than $10 \%$ during Jan-December except the period of April- July, compared with the same period last year and demonstrate a rapid growth since June. In March, July, and October 2020, the monthly imports volume from Bulgaria to China exceeded the monthly exports volume from China to Bulgaria by $20.613,3.877,1.239$ million US dollars respectively. The situation is reversed in the other nine months, but the monthly trade surplus decreased to only 9.04 million US dollars in September because of the steady growth of Chinese imports from Bulgaria. Although the cumulative trade surplus ranged from 11.3 million US dollars to 177.9 million US dollars since April, the trade deficit amounted to 36.4 million US dollars in the first three months when China was in the severest time of fighting with the COVID-19. 


\section{Articles}

Sino-Bulgarian Economic Relations in the Post

Pandemic World

With the 3.2 percent GDP growth rate in the second quarter of 2020, China's economy has rebounded since June, which terminated the slowdown and began the rapid growth trend

of monthly imports and cumulative volume of trade since July, and the total cumulative growth rate in December reaches 7.3 percent, the highest level in 2020.

Table 2. Bulgaria's Unemployment Rate in $\mathbf{2 0 2 0}$

\begin{tabular}{|l|r|l|r|}
\hline \multicolumn{1}{|c|}{ Month } & \multicolumn{1}{c|}{ Unemployment Rate } & \multicolumn{1}{c|}{ Month } & Unemployment Rate \\
\hline March & $6.7 \%$ & August & $7.5 \%$ \\
\hline April & $8.9 \%$ & September & $7.2 \%$ \\
\hline May & $9 \%$ & October & $6.9 \%$ \\
\hline June & $8.3 \%$ & November & $6.7 \%$ \\
\hline July & $7.9 \%$ & December & $6.7 \%$ \\
\hline
\end{tabular}

Source: Collected from China Customs.

Table 3. China's Trade with Bulgaria during in 2020 (Unit: thousand US dollars)

\begin{tabular}{|c|c|c|c|c|c|c|c|c|c|}
\hline \multirow{2}{*}{ Month(s) } & \multicolumn{2}{|c|}{ Total volume of trade } & \multicolumn{2}{|c|}{ Exports to Bulgaria } & \multicolumn{2}{|c|}{ Imports from Bulgaria } & \multicolumn{3}{|c|}{$\begin{array}{l}\text { Cumulative growth over the same period } \\
\text { last year } \pm \%\end{array}$} \\
\hline & monthly & cumulated & monthly & cumulated & monthly & cumulated & Total & Exports & Imports \\
\hline Jan-Feb & 388,335 & 388,335 & 1 & 185,851 & 1 & 202,484 & -5.9 & -23 & 18.2 \\
\hline March & 227,500 & 616,713 & 103,444 & 290,172 & 124,057 & 326,540 & -4.4 & -17 & 10.7 \\
\hline April & 209,764 & 826,919 & 128,510 & 419,086 & 81,254 & 407,832 & -5.3 & -11 & 1.4 \\
\hline May & 221,092 & $1,048,551$ & 142,102 & 561,212 & 78,990 & 487,340 & -6.5 & -7.6 & -5.2 \\
\hline June & 225,294 & $1,274,484$ & 119,160 & 680,428 & 106,134 & 594,056 & -4.3 & -7 & -1 \\
\hline July & 268,555 & $1,543,039$ & 132,339 & 812,767 & 136,216 & 730,272 & -0.7 & -7.3 & 7.9 \\
\hline August & 261,342 & $1,804,381$ & 138,709 & 951,476 & 122,633 & 852,905 & 0.9 & -6.7 & 10.9 \\
\hline September & 269,353 & $2,073,734$ & 139,200 & $1,090,675$ & 130,153 & 983,058 & 3 & -5.4 & 14.3 \\
\hline October & 273750 & $, 2,347,484$ & 136,256 & $1,226,931$ & 137,495 & $1,120,553$ & 3.8 & -4.2 & 14.4 \\
\hline November & 284,182 & $2,631,666$ & 161,892 & $1,388,823$ & 122,290 & $1,242,843$ & 6.7 & -2.1 & 18.7 \\
\hline December & 285,619 & $2,916,844$ & 158,998 & $1,547,380$ & 126,622 & $1,369,464$ & 7.3 & -0.5 & 17.6 \\
\hline
\end{tabular}

\section{Prospect}

Through the above discussion, opportunities and challenges coexist for the prospect of Sino-Bulgarian economic relations in the post pandemic era.

The main challenges may consist of the following four aspects. Firstly, the culture distance may make the Chinese investors unable to cooperate with the local firms and other stakeholders efficiently. Secondly, due to the uncertainty of the COVID-19 pandemic, the global economy was heavily affected. It will take some time for the recovery of the global economy, especially Bulgarian and Chinese economy. Bulgarian business environment may worsen and some preferential policies may become unstable. Thirdly, the stringent regulatory scrutiny from the EU is an unfavorable factor, which is sure to hinder the development of the SinoBulgarian economic relations. Finally, most of Bulgaria's infrastructures are needed to be improved, which is clearly not beneficial to attract FDI.

In spite of the various barriers ahead, there are still a lot of opportunities to improve the bilateral economic relations. From the perspective of Bulgaria, based on the results in the literature, the following four favorable factors: good political relations between the 


\section{Articles}

two countries, the high-quality and low-cost of Bulgarian labor, low tax policy, Bulgaria's strategic geographic position and access to the EU market, are very helpful to enhance the economic relations between China and Bulgaria.

From the perspective of China, China obtained the great victory of controlling the COVID-19 pandemic in the end of March and at the same time, the resumption of work and production has been in orderly manner. As a result, the Chinese economy has strongly rebounded since June 2020 and the growth rate in 2020 reaches 2.3 percent, which makes China become the only country to realize a positive GDP growth rate among the major economies. By sharing experiences in the treatment of COVID-19 with the BR countries, China has been pushing forward the BRI and "17+1" cooperation mechanism to cooperate with countries along the BR and CEECs and foster more economies' recovery. With the huge market and strong consumption ability in China, there is still a big potential for the existing Sino-Bulgarian cooperation in agriculture and food processing, transportation, information technology, finance, clean energy, tourism, digital economy and construction projects etc. The pandemic has incurred a great loss to global economy but boosted the online industries such as online medical treatment, online education, online working and E-commerce, which are probably the new potential cooperation fields for the two countries in the post pandemic world.

\section{Conclusion}

Bulgaria has long-lasting good relations with China since 1949. Benefiting from the BRI and "17+1" cooperation mechanism, the economic relation between China and Bulgaria has been greatly strengthened in recent years. The outbreak of the COVID-19 pandemic brought about a huge negative effect on the global economy. Therefore, exploring the Sino-Bulgarian economic relations in the post pandemic world is urgent and important. Through the literature review, this paper systematically sorts out the existing research on Sino-Bulgarian economic relations. This paper observes that much less researches focus on the Sino-Bulgarian economic relations than their counterparts under the BRI and "17+1" cooperation framework. Adopting a large amount of the data from different authoritative sources, the paper examines the characteristics and dynamics of China's FDI in Bulgaria and the bilateral trade during 2013-2019, and finds out that both China's FDI and the bilateral trade between the two countries in recent years have made great progress than before but still remain unstable and far below the potential.

This paper then analyzes the current situation of Bulgaria's economic development in 2020 based on the latest data. Finally, it provides the prospect of Sino-Bulgarian economic relations by summarizing the opportunities and challenges, and proposes the potential cooperation areas in the end. There is a very promising future for the bilateral economic relations even in countering many challenges and risks in the post pandemic world. The results of this paper can be useful for policy-makers and various stakeholders.

\section{References}

Ahmed, Z.S., 2018. Impact of the ChinaPakistan Economic Corridor on NationBuilding in Pakistan. Journal of Contemporary China, 28(117), pp. 1-15.

Alon, I., Anderson, J., Munim, Z. H., Ho, A., 2018. A Review of the Internationalization of Chinese Enterprises. Asia Pacific Journal of Management, 35(3), pp. 573-605.

Beeson, M.,2018. Geoeconomics with Chinese Characteristics: the BRI and China's Evolving 


\section{Articles}

Grand Strategy, Economic and Political Studies, 6(3), pp. 240-256.

Bellak, C., Leibrecht, M. and Romisch, R. , 2007. On the Appropriate Measure of Tax Burden on Foreign Direct Investment to the CEECs. Applied Economics Letters.14(8), pp.603-606.

Blanchard, J.M.F., 2017. Probing China's Twenty-First-Century Maritime Silk Road Initiative (MSRI): an Examination of MSRI Narratives, Geopolitics, 22(2), pp. 246-268.

Blanchard, J.-M.F. and Flint, C., 2017. The Geopolitics of China's Maritime Silk Road Initiative, Geopolitics, 22(2), pp. 223-245.

Casarini, N. 2016. When All Roads Lead to Beijing. Assessing China's New Silk Road and Its Implications for Europe. The International Spectator, 51(4), pp. 95-108.

Chen H., Yang C., 2015. Study on International Economic Effects of "One Belt and One Road" National Strategy Based on CGE Model. Journal of International Trade, 2015(10), pp. 4-13.

Clarke, M., 2017. The Belt and Road Initiative: China's New Grand Strategy? Asia Policy, 24(1), pp. 71-79.

Cui, L. and Song, M., 2019, Economic Evaluation of the Belt and Road Initiative from an Unimpeded Trade Perspective. International Journal of Logistics Research and Applications, 22(1), pp. 25-46.

Dornean A., Isan V., Oanea D C., 2012. The Impact of the Recent Global Crisis on Foreign Direct Investment. Evidence from Central and Eastern European Countries. Procedia Economics and Finance, 3(1), pp. 1012-1017.

Du, J., and Zhang Y., 2018. Does One Belt One Road initiative Promote Chinese Overseas Direct Investment? China Economic Review, 47, pp. 189-205.

Fan, Z., Zhang, R., Liu, X., Pan, L., 2016. China's Outward FDI Efficiency along the Belt
Sino-Bulgarian Economic Relations in the Post

Pandemic World

and Road. China Agricultural Economic Review, 8(3), pp. 455-479.

Flint, C. and Zhu, C., 2019. "The Geopolitics of Connectivity, Cooperation, and Hegemonic Competition: the Belt and Road Initiative". Geoforum, 99, pp. 95-101.

Huang, Y., 2016. Understanding China's Belt \& Road Initiative: Motivation, Framework and Assessment, China Economic Review, 40, pp. 314-321.

Hunya, G., Galgoczi, B., 2006. FDI Patterns and Trends in Central and Eastern Europe with Particular regard to the New Member States. Transfer, 12(4), pp. 521-537.

lqbal, B.A., Sami, S., Turay, A., 2019. Determinants of China's Outward Foreign Direct Investment in Asia: a Panel Data Analysis, Economic and Political Studies, 7, pp. 66-86.

Jakóbowski, J., Kaczmarski, M., 2017. Beijing's Mistaken Offer: the ' $16+1$ ' and China's Policy towards the European Union. OSW commentary, No 250, pp.1-7.

Jiang, L., 2020. Sino-Bulgarian Economic and Trade Cooperation under the "17+1" Platform and the Belt and Road. Journal of Eurasian economy, 2, pp.111-124.

Justin P., 2016. The Rise of China: What, When, Where, and Why? The International Trade Journal, 30, 3, 207-222.

Kameliya, F., 2016. Analysis of the Factors Influencing Bulgaria-China Trade Competitiveness Index before and after Bulgaria's Accession to the European Union. International Conference on Humanities and Social Science, 1, pp. 609-614.

Kandilarov, E., 2015. The Economic Relations between Bulgaria and China in the Context of "One Belt, One Road" Initiative. Bulgarian Historical Review, 3-4, pp. 48-68.

Kandilarov, E., Dimitrov A., 2018. BulgariaChina Relationship: Between the National 


\section{Articles}

Development Strategy and Belt and Road Initiative. Godishnik na UNSS, 1, 33-73.

Kandilarov, E., Wang Y., 2018. China and CEECs Relations in the Past 40 Years: Achievements, Challenges and ProspectBulgarian point of view. Journal of Xi'an Jiaotong University (Social Sciences), 38(6), pp. 76-82.

Khan, M., Sandano, I., Pratt, C. and Farid, T., 2018. "China's Belt and Road Initiative: a Global Model for an Evolving Approach to Sustainable Regional Development". Sustainability, 10 (11), pp. 1-20.

Kohl, T., 2019. The Belt and Road Initiative's Effect on Supply-Chain Trade: Evidence from Structural Gravity Equations, Cambridge Journal of Regions, Economy and Society, 12(1), pp. 77-104.

Li, Q., Liang, Q., 2012. Political Relations and Chinese Outbound Direct Investment: Evidence from Firm and Dyadic-Level Test, Working Paper.

Li, Z., Huang, Z. and Dong H., 2019. The Influential Factors on Outward Foreign Direct Investment: Evidence from the "The Belt and Road". Emerging Markets Finance and Trade, 55(1), pp. 1-16.

Liu, H., Tang, Y., Chen, X.L. and Ponznanska, J., 2017. The Determinants of Chinese Outward FDI in Countries Along "One Belt One Road". Emerging Markets Finance and Trade, 53(6), pp. 1374-1387.

Liu Y. H., Zhao, X.H., Zhang, J., 2020. An Empirical Research on the Efficiency and Potential of China's OFDI in Central and Eastern Europe. Journal of Shanghai University (Social Science Edition), 37(4), pp. 46-57.

Liu, Z., 2013. Analysis of Chinese Investment in Eastern Europe. China International Studies, 1, pp. 108-120.

Liu, Z., 2014. The Analysis of China's Investment in V4', in Current Trends and Perspectives in Development of China-V4
Trade and Investment, Bratislava, 12-14 March (Bratislava, University of Economics in Bratislava, Faculty of International Relations).

Liu, Z., 2020. The Development History and Prospect of Cooperation between China and Central and Eastern European countries. Contemporary World, 4, pp. 4-9.

Lo, C., 2015. China's Silk Road Strategy: The Opportunities and Pitfalls of 'Killing Three Birds with One Stone'. The International Economy, 29(4), pp. 54-55.

Lu, Y., Lu, Y., Zeng, Ka., Li, Y., 2018. China's Outward Foreign Direct Investment and the Margins of Trade: Empirical Evidence from "One Belt, One Road" Countries. China: An International Journal, 16(1), pp. 129-151.

Malik, J.M., 2018. Myanmar's Role in China's Maritime Silk Road, Journal of Contemporary China, 27(111), pp. 362-378.

Mao, H., Liu, G., Zhang, C. and Muhammad Atif, R., 2018, Does Belt and Road Initiative Hurt Node Countries? A Study from Export Perspective. Emerging Markets Finance and Trade, 55(7), pp. 1-14.

Matura, T., 2019. China-CEE Trade, Investment and Politics. Europe Asia Studies, 71(3), pp. 1-20.

Mumtaz, M. Z., and Smith Z., 2018. The Determinants of Chinese Outward Foreign Direct Investment: A Closer Look. Frontiers of Economics in China,13(4), pp. 577-601.

Narins, T.P. and Agnew, J., 2019. Missing from the Map: Chinese Exceptionalism, Sovereignty Regimes and the Belt Road Initiative. Geopolitics, pp.1-29.

Poncet, S., 2015, China's Emergence and Its Implications for Europe's Economies, Global Economic Review, 44(4), pp. 387-419.

Shang, Y., Gao, Y., 2014. Relationship of Competitiveness of Exporting Products and Their Structural Effects between China and CEECs during 2002-2011: An Empirical Study 


\section{Articles}

Based on Constant Market Share Analysis Model. World Economy Studies, 4, pp. 32-38.

Turcsanyi, Richard Q., 2017. Central European Attitudes Towards Chinese Energy Investments: The cases of Poland, Slovakia, and the Czech Republic. Energy Policy, 101, pp. 711-722.

Wang, M.L., Qiu, Q. and Choi, C.H., 2019, How Will the Belt and Road Initiative Advance China's Exports. Asia Pacific Business Review, 25(1), pp. 81-99.

Wang, P., Pan, X., Zhang, S., 2018. Institutional Factors, Bilateral Investment Treaties and China's OFDI Location Selection--Based on the Panel Data of Countries along "The Belt and Road". Review of Economy and Management, pp. 1, 5-17.

Yang C, Chen H., 2016. The Impact of China OFDI on the Export Trade Transformation and Upgrade-Empirical Analysis Based on China and Central and Eastern Europe. International Business, 6, pp. 83-96.
Sino-Bulgarian Economic Relations in the Post

Pandemic World

Zhai, F., 2018. "China's Belt and Road Initiative: a Preliminary Quantitative Assessment". Journal of Asian Economics, 55, pp. 84-92.

Zhang S., 2017. Layout Optimization of China's Outward Foreign Direct Investment in the Context of "One Belt One Road Initiative". Management World, 4, pp. 1-9.

Zhang, Y., 2016. The Investment Facilitation of "One Belt One Road" and Choices of China's Foreign Direct Investment-Empirical Analysis Based on Cross-Panel Data and Investment Gravity Model. Journal of International Trade, 9, pp. 165-176.

Zhelev, P., 2018. Bulgarian-Chinese Economic Relations in the Context of $16+1$ Cooperation. China-CEE Institute Working Paper, 24, pp. 2560-1628.

Zheng, J. and Wang Z., 2020. "One Belt and One Road" in the Context of COVID-19: Review and Outlook. Economic Research in Northeast Asia, 4, pp. 18-33. 